Brazilian Journal

of Chemical

ISSN 0104-6632

Engineering

\title{
PREPARATION OF ZINC OXIDE-NANOCLAY HYBRIDS BY ALKALINE ION EXCHANGE METHOD
}

\author{
N. Garshasbi ${ }^{1}$, M. Ghorbanpour ${ }^{2, *}$, A. Nouri ${ }^{2}$ and S. Lotfiman ${ }^{2}$ \\ ${ }^{1}$ Department of Food Science, Islamic Azad University-Sarab Branch, Sarab, Iran \\ ${ }^{2}$ Chemical Engineering Department, University of Mohaghegh Ardabili, Ardabil, Iran \\ *E-mail: ghorbanpour@uma.ac.ir
}

(Submitted: September 15, 2015; Revised: August 10, 2016; Accepted: August 14, 2016)

\begin{abstract}
ZnO} /$ nanoclay hybrids are synthesized by a single-step solid-state reaction using $\mathrm{ZnCl}_{2}$ as a reagent. These hybrids were prepared by a simple alkaline ion exchange method, without using any surfactant or chelating agents. By adjusting the reagent's immersion time in molten salt, production of pure $\mathrm{ZnO}$ /nanoclay hybrids was achieved. Synthesized hybrids were characterized by UV-vis diffuse reflectance spectroscopy, XRD, XRF and SEM. SEM confirmed increased nanoclay porosity. The XRD pattern of the $\mathrm{ZnO} /$ nanoclay indicated small changes in the intensity and position of the interlayer spacing of montmorillonite. Antibacterial activity of the hybrids against Escherichia coli and Staphylococcus aureus were assessed using disc diffusion. The results show that the antibacterial efficiency of the hybrid is not influenced by the time or the temperature of ion exchange, but is affected by bacterial type.
\end{abstract}

Keywords: Zinc oxide-nanoclay hybrids, alkaline ion exchange method, antibacterial activity.

\section{INTRODUCTION}

Zinc oxide nanoparticles possess several interesting properties, such as optical transparency, electric conductivity, piezoelectricity, nontoxicity, wide availability, low cost and stability. The specific properties of nanoscale zinc oxide particles have found a wide range of applications, including luminescence, varistors, solar cells and gas sensors (Kołodziejczak-Radzimska, 2014).

It has been demonstrated that $\mathrm{ZnO}$ nanostructures exhibit antimicrobial activity against a broad spectrum of bacteria, including Staphylococcus aureus (Applerot et al. 2009; Gordon et al., 2011; Pouraboulghasem et al., 2016 b; Yamamoto, 2001) and Escherichia coli (Brayner et al., 2005; Franklin et al., 2007; Gilani et al., 2016). They are currently used in many cosmetics and food packaging applications. Unlike conventional chemical disinfectants, these antimicrobial nanomaterials are not expected to produce harmful disinfection byproducts. The antimicrobial activity of $\mathrm{ZnO}$ nanoparticles may be related to the induction of oxidative stress due to the generation of reactive oxygen species, which may cause the degradation of the bacterial membrane structure (Sawai et al., 1998). Disruption of the bacterial membrane is attributed to peroxidation of the unsaturated phospholipids due to photocatalytically induced hydrogen peroxide. The presence of $\mathrm{ZnO}$ nanoparticles damages the bacterial membrane and cell wall. Consequently, bacterial growth

\footnotetext{
* To whom correspondence should be addressed
} 
is inhibited. In addition, binding $\mathrm{Zn}^{2+}$ to microorganisms' membranes prolongs the lag phase of the microbial growth cycle (Brayner et al., 2005; Atmaca et al., 1998).

Sol-gel, spray pyrolysis, precipitation, microemulsion techniques, electrophoretic deposition, thermal evaporation, laser ablation, chemical vapor deposition, mechanical milling, molten salt and microwave method and hydrothermal synthesis are some of the methods employed in synthesizing nanoparticles (Espitia et al., 2012; Ghorbanpour and Lotfiman, 2016; Payami et al., 2016; Srivastava et al., 2013; Zhu and Zhou, 2008). However, all of these approaches involve complex apparatus or processing. They also involve toxic reagents or additives. The relatively high temperature, complexity and toxicity of these techniques restrict their widespread application. On the other hand, in most of these techniques, nanoparticles tend to agglomerate due to their high surface energy. Therefore, nontoxic, simple, low cost and high yield synthetic methods for preparing nanometric materials are keenly pursued.

The alkaline ion exchange method offers easy control of zinc loading, an environmentally friendly approach with large scale production via fast processing. Furthermore, this method introduces a process with inexpensive raw materials and uncomplicated equipment (Pouraboulghasem et al., 2016 a, Tagantsev et al., 2008; Xu e al., 2007). It also provides a way to fabricate samples easily by introducing zinc into clay. Molten salt ion exchange is a well-known method investigated for the last few decades to introduce ions into silicate glass, e.g., for waveguides in optical applications (Oven et al., 2004; Newby et al., 2011). Alkaline ion exchange in clay minerals can be simply stated as:

$$
2 \mathrm{Na}^{+}{ }_{\text {(Clay) }}+\mathrm{Zn}^{2+}{ }_{\text {(melt) }}=>\mathrm{Zn}^{2+}{ }_{\text {(Clay) }}+2 \mathrm{Na}^{+}{ }_{\text {(melt) }}
$$

Nanoclay is used primarily for synthesizing nanocomposites and biodegradable materials to improve mechanical and thermo properties (Rhim and Wang, 2014; Arora and Padua, 2010). To create nanocomposites' antibacterial activity, nanoparticles with antibacterial activity must be used. Zinc is a common component in this approach. However, synthesizing nanoparticles is complicated, and nano products create another serious problem in the environment. Therefore, introducing a fast and inexpensive method for synthesis with production on an industrial scale is an outcome in high demand.

To our knowledge, this is the first time that zinc oxidenanoclay hybrids have been synthesized by alkaline ion exchange. The advantages of this method are simplicity and speed in the production of the pure product, particularly because no solvent or special preparation was required. For this approach nanoclay was mixed with solid $\mathrm{ZnCl}_{2}$ at the salt melting point temperature. The main parameters to investigate were time and temperature. The produced nanocomposite was characterized by various techniques.
Experiments carried out to investigate the efficiency of the synthesized hybrids against bacteria are explained in detail.

\section{MATERIALS AND METHODS}

\section{Materials}

Nanoclay (K10 montmorillonite) used as a solid support for zinc was obtained from Sigma-Aldrich (Tehran, Iran). Zinc chloride and Nutrient agar was purchased from Merck (Tehran, Iran). The bacterial strains used for the antibacterial activity were gram-negative $E$. coli (PTCC 1270) and gram-positive S. aureus (PTCC 1112) obtained from the Iranian Research Organization for Science and Technology (Tehran, Iran). All reagents were analytical grade and used without further refinement.

\section{Alkaline ion exchange with zinc}

The alkaline ion exchange process began with immersion of nanoclay into $\mathrm{ZnCl}_{2}$ at 350 and $450{ }^{\circ} \mathrm{C}$ for $1,2,3$ and $5 \mathrm{~min}$. This step was conducted using 1 $\mathrm{g}$ of nanoclay and $1 \mathrm{~g}$ of $\mathrm{ZnCl}_{2}$. After ion exchange, the nanoclay was adequately washed with distilled water and sonication. After filtration, the hybrids were dried in an oven at $25^{\circ} \mathrm{C}$.

\section{Characterization methods}

\section{Scanning electron microscopy}

The morphology of samples was observed with a scanning electron microscope (LEO 1430VP, Germany).

\section{$X$-ray powder diffraction}

X-ray diffraction (XRD) patterns were recorded using a Philips PW 1050 diffractometer (The Netherlands). Samples in powder form were pressed in a rotational holder. Reflection mode was used for all measurements.

\section{X-ray fluorescence spectroscopy}

Chemical composition of the samples was determined using a $\mu$-energy dispersive fluorescence spectrometer (XMF-104 X-ray Micro analyzer, Unisantis S.A., Switzerland) equipped with a $50 \mathrm{~W}$ molybdenum tube and a high resolution two-stage Peltier cooled Si-PIN detector (Amptek, USA). The samples were positioned in definite places, but at a constant height from the holder base. The temperature was controlled at $32-34{ }^{\circ} \mathrm{C}$ throughout the experiments. Voltage and current were $30 \mathrm{kV}$ and $300 \mu \mathrm{A}$, respectively. Each micro-EDXRF analysis was performed in $50 \mathrm{~s}$ to obtain sufficient counts (Ghorbanpour and Falamaki, Applied Optics, 2012). 


\section{UV-Vis diffuse reflectance spectroscopy (DR UV-Vis)}

DR UV-Vis was used for a qualitative description of the differences in absorbance depending on the amount of $\mathrm{ZnO}$ in the studied composites. DR UV-Vis of the powder samples was conducted in a $5.0 \mathrm{~mm}$ quartz cell registered in the wavelength range of $200-800 \mathrm{~nm}$ using a spectrophotometer (Scinco S4100, S. Korea).

\section{Leaching tests}

In order to evaluate the stability of the hybrids, leaching tests were performed. For each composite material, $0.2 \mathrm{~g}$ was immersed in $10 \mathrm{~mL}$ of distilled water and vigorously shaken in a shaking water bath $\left(30{ }^{\circ} \mathrm{C}, 200 \mathrm{rpm}\right)$ for 24 h. Supernatants from each test tube were collected by centrifugation at $4000 \mathrm{rpm}$ for $10 \mathrm{~min}$. Zinc ions released from hybrids were qualitatively determined by atomic absorption spectroscopy analysis (Varian/AAS, 20BQ, USA).

\section{Antibacterial activity}

The antibacterial activity of the $\mathrm{ZnO} /$ nanoclay hybrids against both $E$. coli (gram-negative) and $S$. aureus (grampositive) was tested by agar diffusion test. Samples were exposed to bacteria in solid media (nutrient agar), and the inhibition zone around each sample was measured and recorded as the antibacterial effect of $\mathrm{ZnO}$ nanoparticles. Agar plates were inoculated with $100 \mu \mathrm{L}$ suspensions of bacteria. Hybrids were placed on $0.5 \mathrm{~cm}$ diameter agar disks and incubated at $37^{\circ} \mathrm{C}$ for $24 \mathrm{~h}$. The inhibition zone for bacterial growth was detected visually.

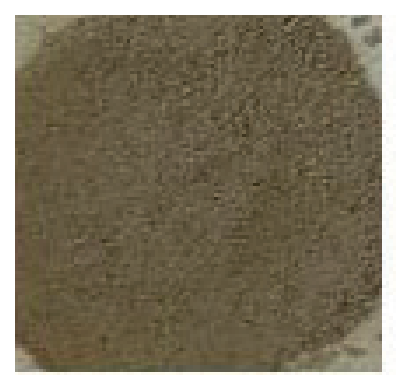

(a)

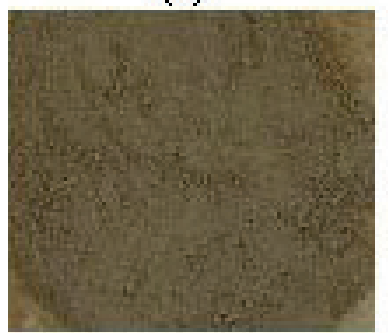

(e)

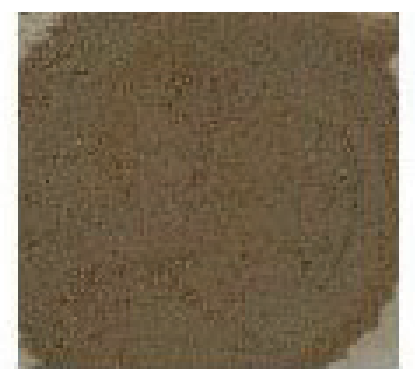

(b)

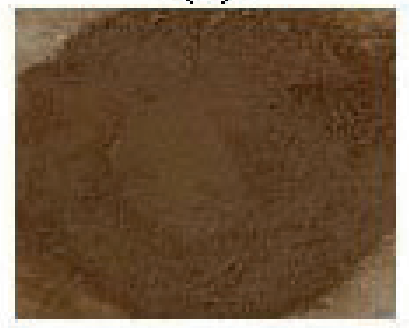

(f)

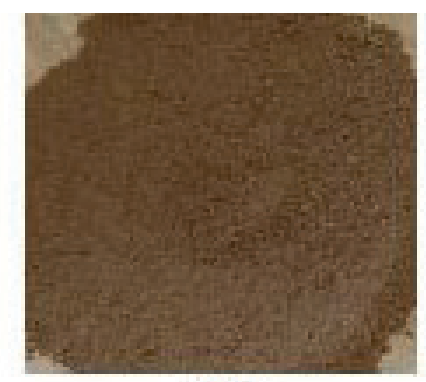

(c)

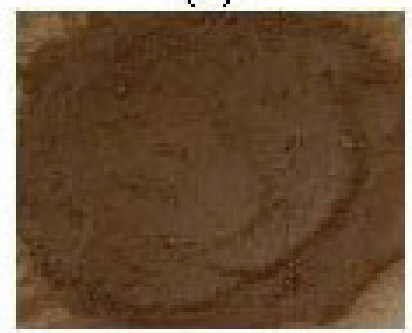

(g)

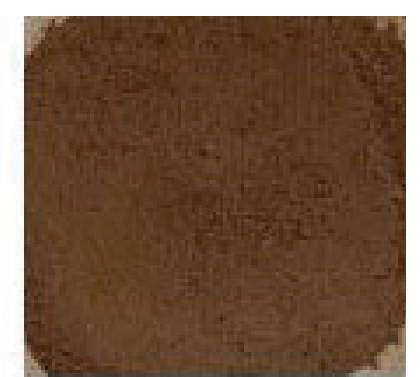

(d)

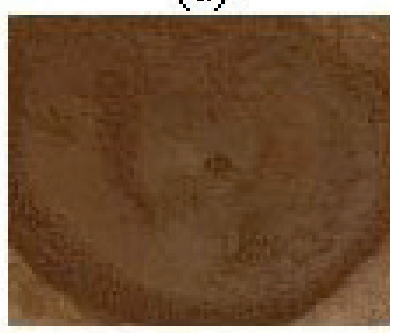

(h)

Figure 1. Photographs of ion-exchanged nanoclay at $350^{\circ} \mathrm{C}$ for 1 (a), 2(b), 3 (c) and $5 \mathrm{~min}(\mathrm{~d})$, and at $450{ }^{\circ} \mathrm{C}$ for 1 (e), 2 (f), 3 (g) and $5 \mathrm{~min}$ (h). 


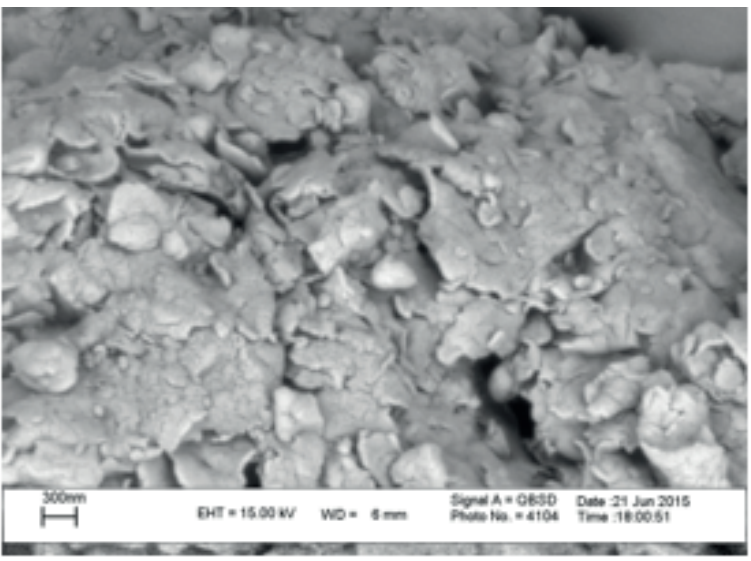

(a)

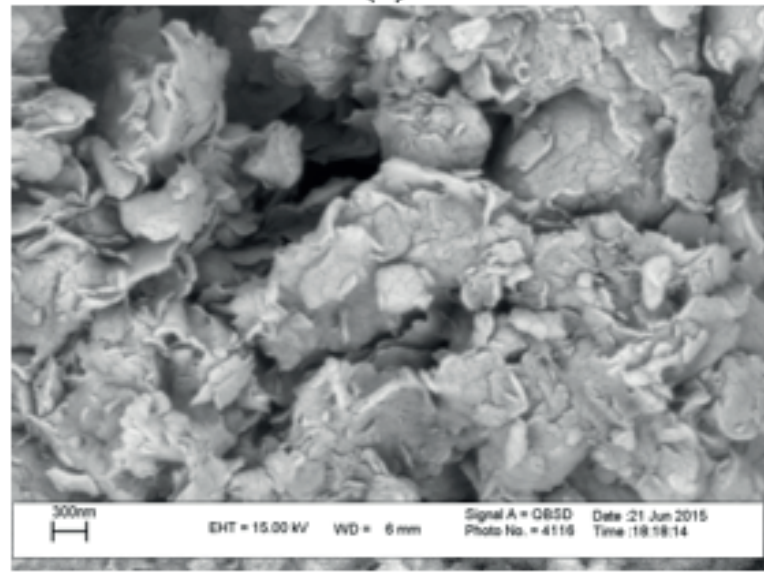

(c)

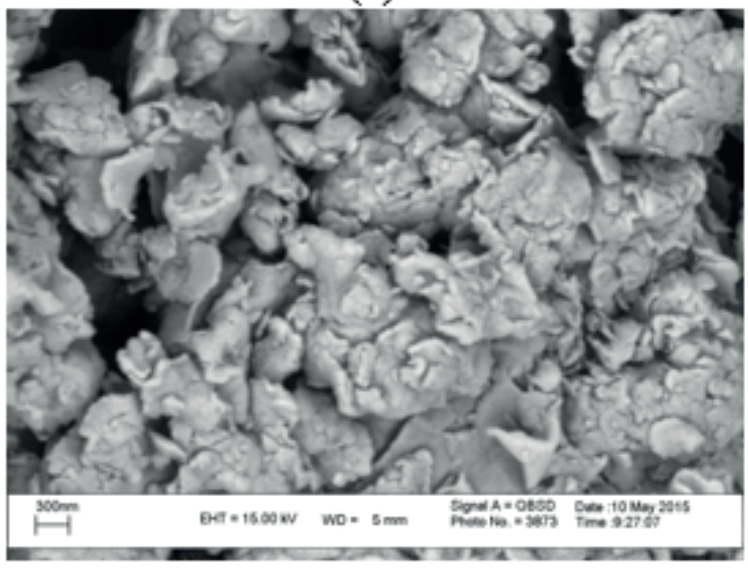

(e)

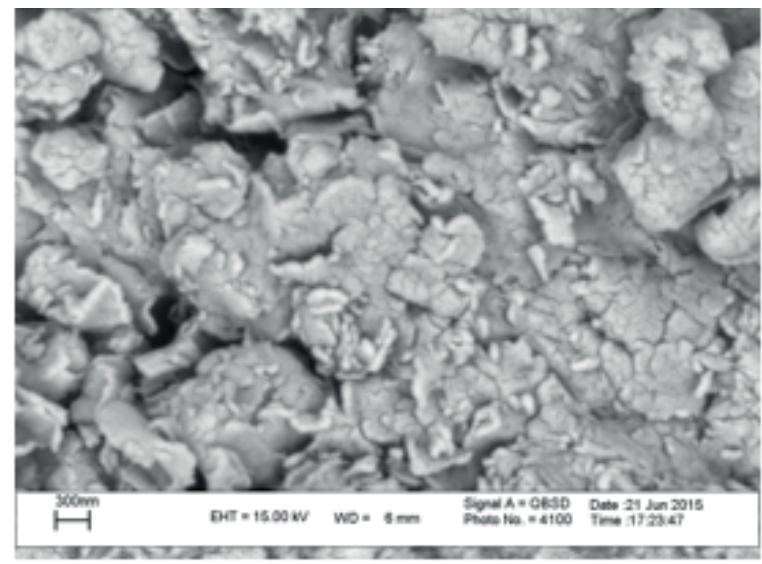

(b)

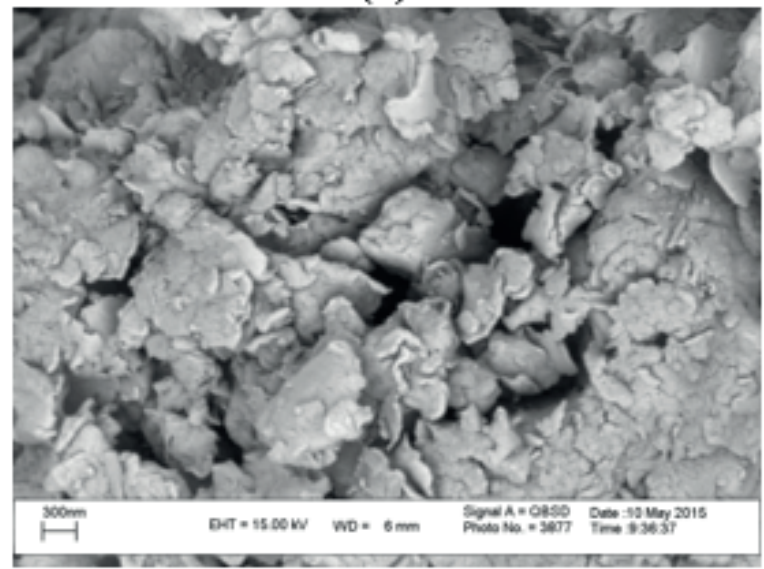

(d)

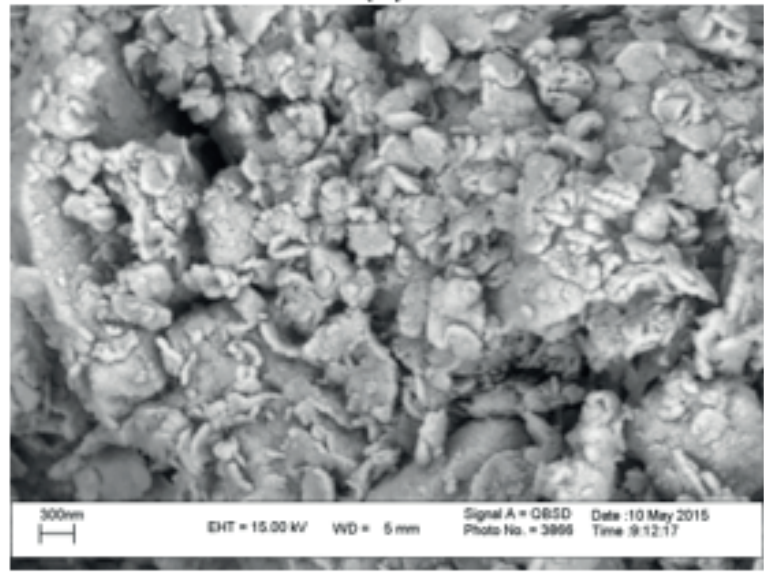

(f)

Figure 2. SEM images of parent nanoclay (a) and ion exchanged nanoclay at $350{ }^{\circ} \mathrm{C}$ for 2 (b) and 5 (c) minutes and at $450{ }^{\circ} \mathrm{C}$ for 1 (d), 3 (e), and 5 minutes (f).

\section{XRD analysis}

XRD patterns of the $\mathrm{ZnO} /$ nanoclay hybrid prepared by the alkaline ion exchange method at 350 and $450{ }^{\circ} \mathrm{C}$ in the $2 \theta$ range of $4-60^{\circ}$ are shown in Figure 3 . Nanoclay characteristic peaks are shown at $2 \theta$ values of 6,20 and $35^{\circ}$, denoted with " $\mathrm{M}$ " on the graph. The peaks are evident in all patterns, and are also consistent with other reported works (Dakovic et al., 2012; Khaorapapong et al., 2011). As can be seen in Figure 3, the XRD pattern of the $\mathrm{ZnO}$ / nanoclay displays small changes in intensity and in the 
position of the interlayer spacing $\left(\mathrm{d}_{001}\right)$ of montmorillonite (1.4 $\mathrm{nm}$ for nanoclay and $1.5-1.6 \mathrm{~nm}$ for $\mathrm{ZnO} /$ nanoclay hybrids). These changes resulted from the expansion of the interlayer spaces, which may be caused by the intercalation of $\mathrm{ZnO}$ particles. Németh et al. (2005) reported the results of XRD analysis of Na-montmorillonite exchanged with Zn solutions through different concentrations. They stated that the characteristic basal reflection of montmorillonite $(1.25 \mathrm{~nm})$ had progressively shifted to $1.4-1.5 \mathrm{~nm}$ after an exchange with zinc. Diffraction peaks corresponding to impurities were not found in the XRD patterns, confirming the high purity of the synthesized products.

\section{XRF analysis}

$\mathrm{XRF}$ analysis was used to investigate the rate and amount of $\mathrm{Zn}$ loading in nanoclay. For this reason, the loading of $\mathrm{Zn}$ within the composites was probed through $\mu$-XRF measurements. The intensity of the loaded zinc atoms was enhanced by increasing the alkaline ion exchange time. However, the intensity increased more rapidly in the first minute, reaching about 2000 counts (Figure 4a). Then the intensity change was low and reached about 2500 counts for $5 \mathrm{~min}$ in exchanged nanoclay at $350{ }^{\circ} \mathrm{C}$ (Figure $4 \mathrm{~b}$ ). This can be explained by diffusion theory. At the beginning of the process $\mathrm{Na}$ ions covered the surface of the nanoclay. Therefore, $\mathrm{Zn}$ ions from the molten salt were rapidly and easily exchanged with $\mathrm{Na}$ ions. This happened in the first minute of the process. Then, mass transfer of $\mathrm{Na}$ and $\mathrm{Zn}$ was accomplished by inner $\mathrm{Na}$ ions. This step is needed for $\mathrm{Zn}$ penetration into nanoclay; therefore, the mass transfer rate and intensity reduce. It was concluded that the majority of $\mathrm{Zn}$ loading on nanoclay was carried out in the first minute.

\section{DR UV-Vis spectra analysis}

The UV-vis absorption spectra of samples are shown in Figure 5. The maximum peak at around $315 \mathrm{~nm}$ belongs to the intrinsic absorption of nanoclay. Parent zinc chloride also has a strong absorption around $306 \mathrm{~nm}$. After ion exchange, the two peaks disappeared. It could be the result of the changes of the initial nanoclay and $\mathrm{ZnCl}_{2}$ to nanocomposite during the process.

All nanocomposites have a strong absorption peak located around $360 \mathrm{~nm}$ and a weak absorption peak located around $433 \mathrm{~nm}$. The two traces for $3 \mathrm{~min}$ process time also indicate higher absorption at higher temperature. Furthermore, the maximum absorption located at around $360 \mathrm{~nm}$ in the samples is slightly red shifted to higher wavelengths by increments of time and temperature in ion exchange. This red shift can be attributed to the agglomerations in the samples (Ghorbanpour and Falamaki, 2013). XRF results revealed that the major loading of $\mathrm{Zn}$ was accomplished within the first min. However, DRS graphs show no changes in the absorption after $3 \mathrm{~min}$. This can be attributed to the changes in composite structure and the connection form of loaded $\mathrm{Zn}$ ions.

\section{Leaching tests}

The leaching test has been developed for the assessment of released zinc ions from nanocomposite. Table 1 shows

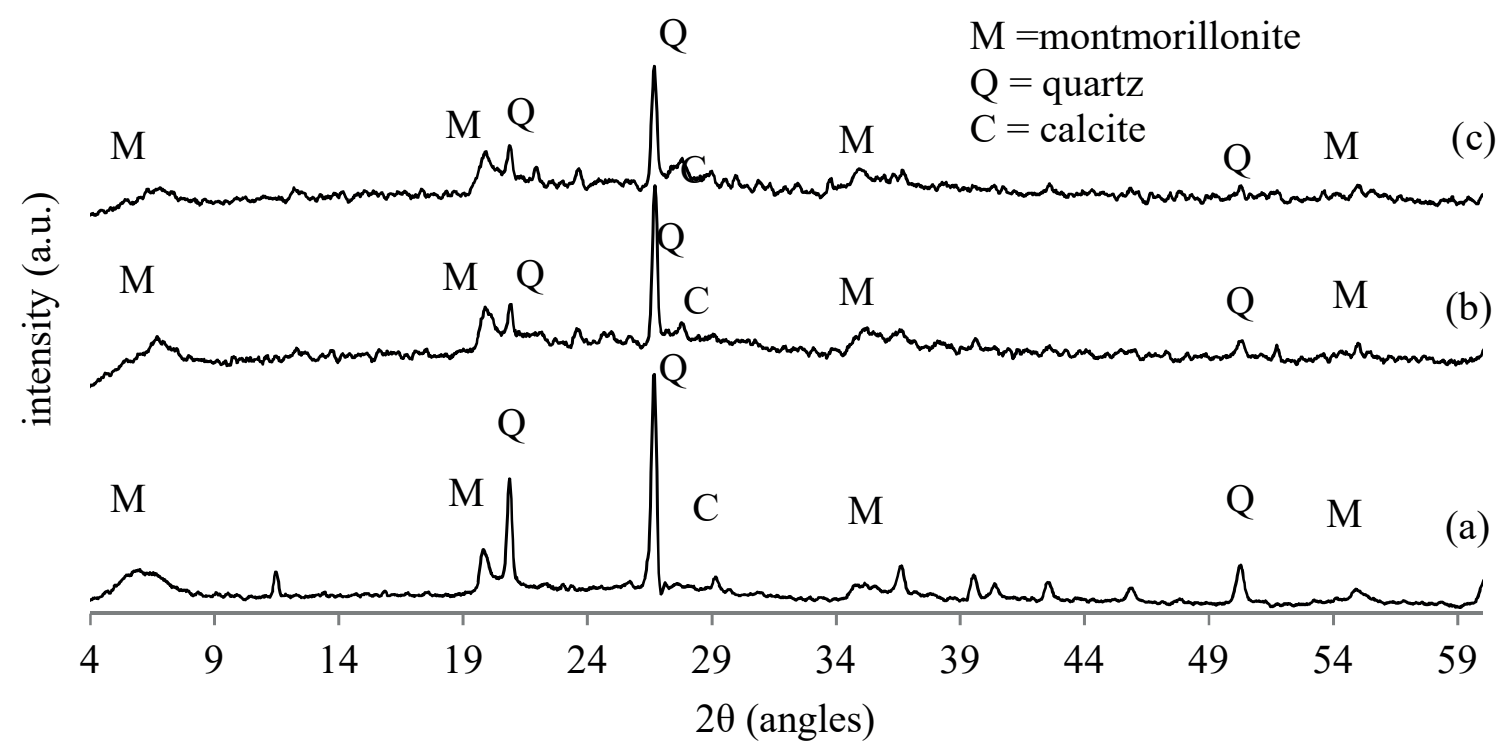

Figure 3. XRD patterns of parent nanoclay (a), ion exchanged nanoclay at $350{ }^{\circ} \mathrm{C}$ for 3 (b) and at $450{ }^{\circ} \mathrm{C}$ for 5 (c). 


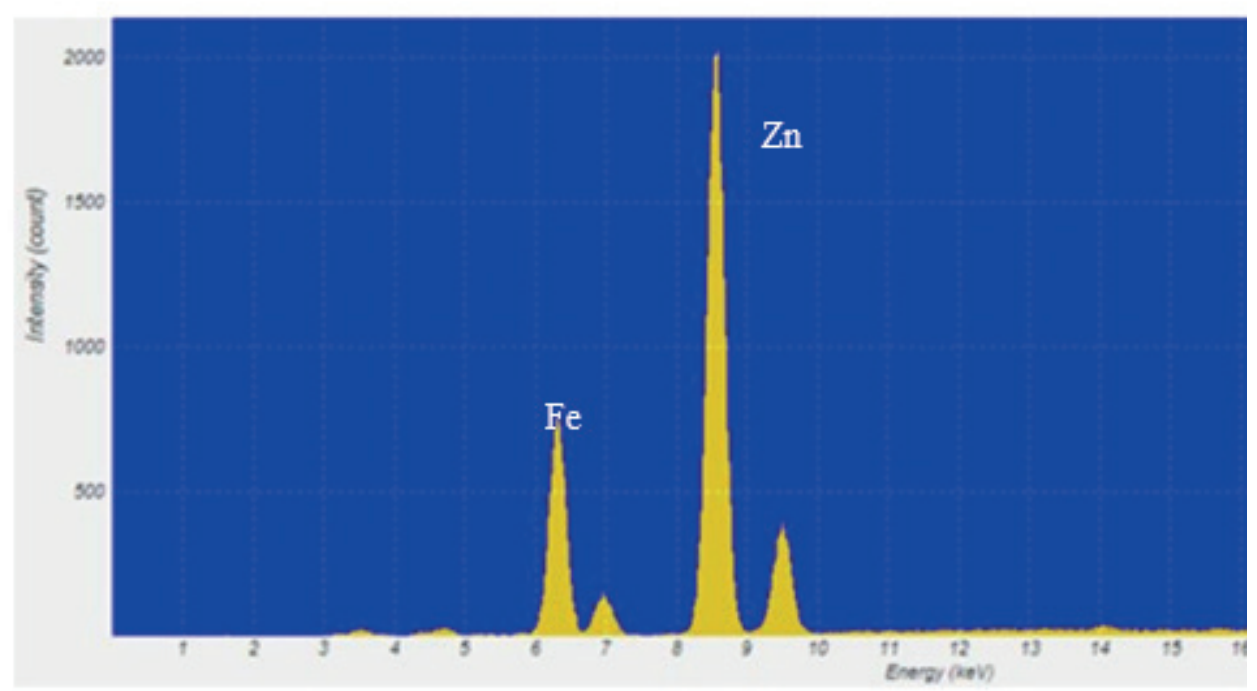

(a)

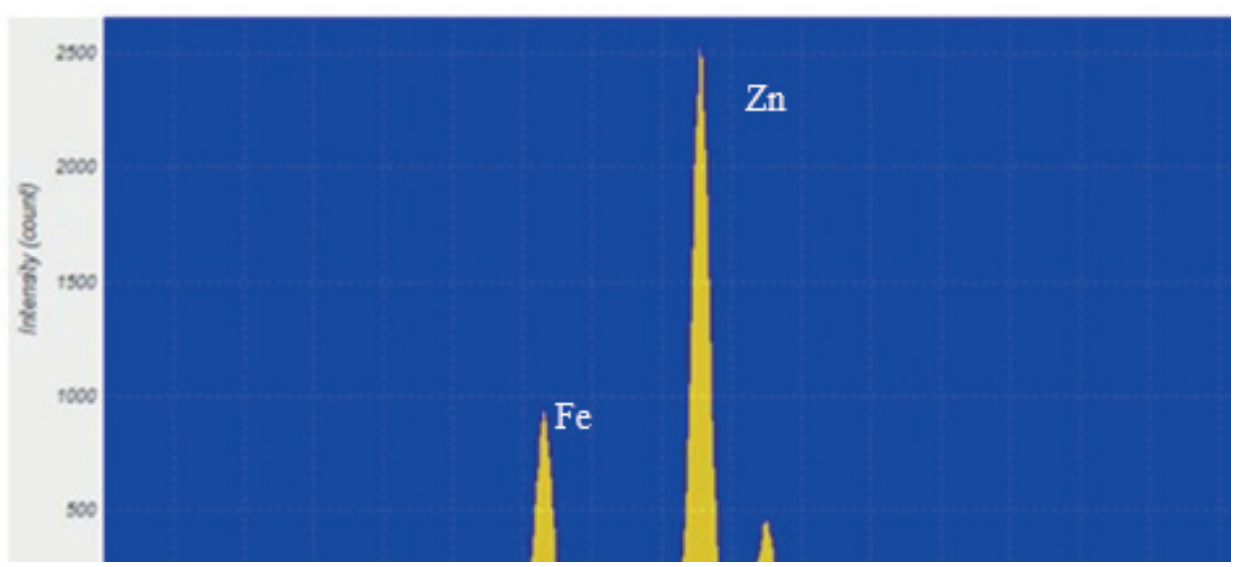

Figure 4. The micro-EDXRF spectrum of ion-exchanged nanoclay at $350{ }^{\circ} \mathrm{C}$ for $1 \mathrm{~min}$ (a) and at $350{ }^{\circ} \mathrm{C}$ for $5 \mathrm{~min}$

Table 1. Zinc concentration in water at different contact times between $\mathrm{ZnO} /$ nanoclay hybrids and aqueous media

\begin{tabular}{|c|c|c|c|c|c|c|}
\hline Ion exchange temperature $\left({ }^{\circ} \mathrm{C}\right)$ & & $350^{\circ}$ & & & $450^{\circ}$ & \\
\hline Ion exchange time (min) & 1 & 3 & 5 & 1 & 3 & 5 \\
\hline Zinc concentration (ppm) & 0.33 & 0.92 & 0.96 & 0.36 & 1.01 & 1.39 \\
\hline
\end{tabular}

that released $\mathrm{Zn}^{2+}$ was low for the samples prepared at 350 ${ }^{\circ} \mathrm{C}, 1 \mathrm{~min}$ and $\mathrm{at} 450{ }^{\circ} \mathrm{C}, 1 \mathrm{~min}$. Longer process time samples released more $\mathrm{Zn}^{2+}$. This may be explained by the position from which $\mathrm{Zn}^{2+}$ was released. As described above, during the first minute $\mathrm{Zn}$ ions were exchanged with surface $\mathrm{Na}$ ions and were set as a structural particle. However, further time allowed $\mathrm{Zn}$ ions to penetrate into the nanoclay. On the other hand, some $\mathrm{Zn}$ ions became entangled into the structure or remained on the surface of nanoclay without binding. The probability of releasing nonbinding $\mathrm{Zn}^{2+}$ is high, so the samples with longer processing time released more $\mathrm{Zn}$ ions.

\section{Antibacterial activity}

The antibacterial properties of $\mathrm{ZnO}$ /nanoclay hybrids were tested comparatively against gram-negative $E$. coli and gram-positive $S$. aureus bacteria by the disk diffusion test. The inhibition zone under and around the tested samples against $S$. aureus was detected visually (Figure 6) and listed in Table 2. The results suggest that the hybrid had a toxic effect on the bacteria. This could be associated with the photocatalytic mechanism of nano $\mathrm{ZnO}$, which generates hydrogen peroxide and causes the degradation of the membrane structure of the bacteria (Sawai et al., 1998; 


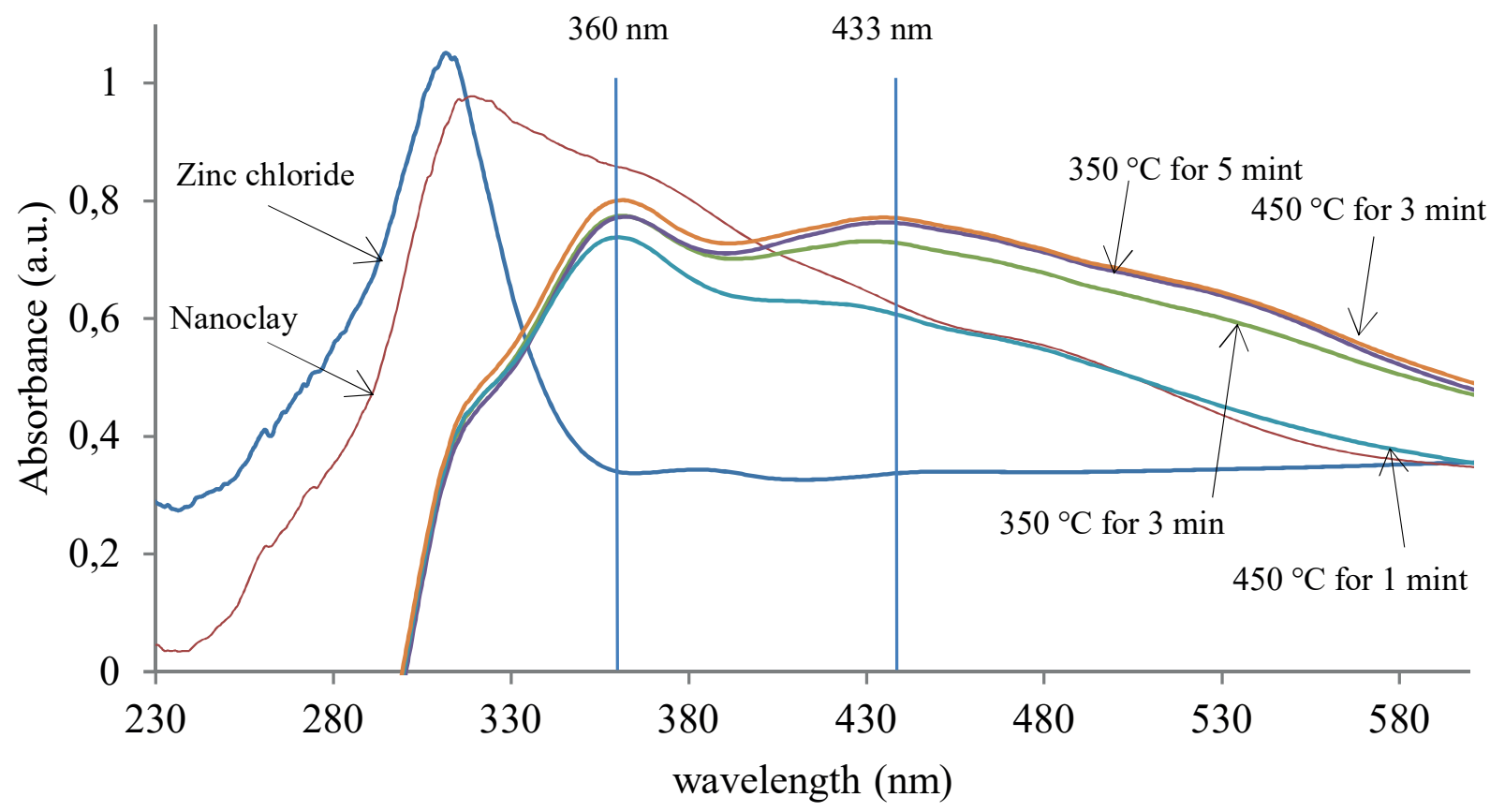

Figure 5. UV-vis absorption spectra of nanoclay and $\mathrm{ZnO} /$ nanoclay hybrids.

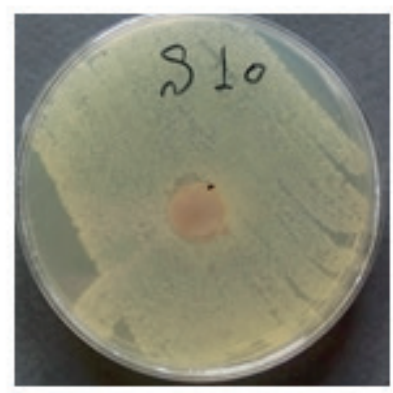

(a)

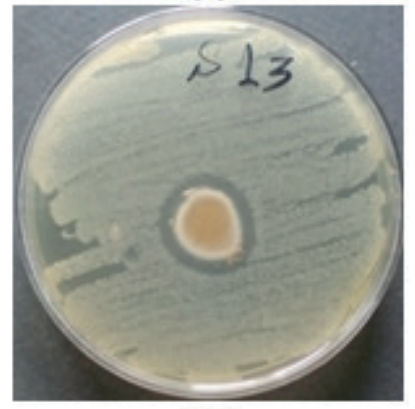

(d)

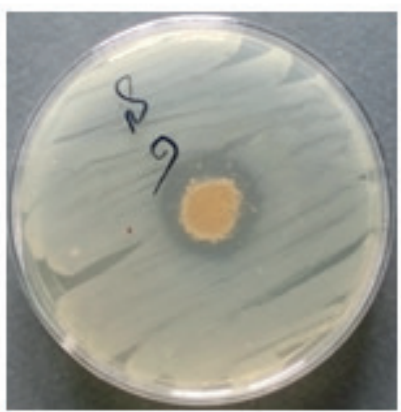

(b)

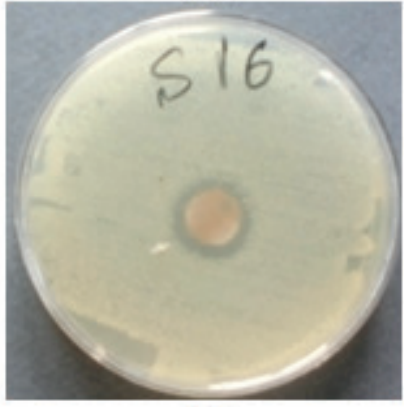

(e)

Figure 6. Inhibition zone of parent nanoclay (a) and ion-exchanged nanoclay at $350{ }^{\circ} \mathrm{C}$ for 2 (b) and 5 (c) minutes and at $450{ }^{\circ} \mathrm{C}$ for 2 (d) and 5 (e) minutes against $S$. aureus 
Table 2. Antibacterial activity of $\mathrm{ZnO}$ /nanoclay hybrids against $E$. coli and $S$. aureus

\begin{tabular}{cccc}
\hline \multirow{2}{*}{ Temperature $\left({ }^{\circ} \mathbf{C}\right)$} & Time (min) & \multicolumn{2}{c}{ Inhibition zone (mm) } \\
\cline { 2 - 3 } & 1 & E. coli & S. aureus \\
2 & $3.23 \pm 0.6$ & $2.52 \pm 0.5$ \\
350 & $3.73 \pm 0.5$ & $3.05 \pm 0.3$ \\
& 5 & $4.27 \pm 0.6$ & $3.35 \pm 0.3$ \\
& 1 & $4.90 \pm 0.7$ & $3.58 \pm 0.2$ \\
2 & $5.48 \pm 0.5$ & $3.19 \pm 0.4$ \\
450 & 3 & $4.82 \pm 0.3$ & $3.07 \pm 0.6$ \\
& 5 & $4.87 \pm 0.4$ & $3.47 \pm 0.4$ \\
& $5.42 \pm 0.6$ & $3.13 \pm 0.3$ \\
\hline
\end{tabular}

Atmaca et al., 1998). The results in Table 2 show that the antibacterial efficiency of the hybrid is not influenced by the time or temperature of ion exchange. Interestingly, antibacterial activity is affected by bacterial type. Gramnegative bacteria provide greater antibacterial effect than gram-positive bacteria.

\section{CONCLUSION}

$\mathrm{ZnO} /$ nanoclay hybrids were successfully synthesized at the first attempt through an easy, simple and fast method, without using any solvents or expensive reagents. Processing time and temperature were the two main factors that influenced the properties of produced nanocomposite. The results revealed that the pore sizes of parent nanoclay were enhanced by increasing temperature and processing time. XRD patterns confirmed the high purity of the synthesized products. It was also obtained that the loading of $\mathrm{Zn}$ ions was faster in the first minute. The loading of $\mathrm{Zn}$ ions increased with increasing process time and temperature. The processing time and temperature had no impact on the antibacterial activity, while the type of bacteria used had an effect on the results. Gram-negative bacteria delivered more antibacterial activity than grampositive bacteria.

\section{REFERENCES}

Arora, A. and Padua, G.W., Review: Nanocomposites in Food Packaging, J. food sci.75, 43 (2010).

Atmaca, S., Gul, K. and Clcek, R., The effect of zinc on microbial growth, Turk. J. Med. Sci. 28, 595 (1998).

Applerot, G., Perkas, N., Amirian, G., Girshevitz, O. and Gedanken, A. Coating of glass with $\mathrm{ZnO}$ via ultrasonic irradiation and a study of its antibacterial properties, Appl. Surf. Sci. 256, S3 (2009).

Brayner, R., Ferrari-Illiou, R., Briviois, N., Djediat, S., Benedetti, M.F. and Fievet, F., Toxicological impact studies based on Escherichia coli bacteria in ultrafine $\mathrm{ZnO}$ nanoparticles colloidal medium, Nano Lett. 6, 866 (2006).
Dakovic, A., Kragovic, M., Rottinghaus, G.E., Ledoux, D.R., Paula Butkeraitis, Vojislavljevic, D.Z., Zaric, S.D., Stamenic, L., Preparation and characterization of zinc-exchanged montmorillonite and its effectiveness as aflatoxin $\mathrm{B}_{1}$ adsorbent, Mat. Chem. Phys. 137, 213 (2012).

Espitia, P.J.P., Soares, N.D.F.F., Dos Reis Coimbra, J.S., De Andrade, N.J., Cruz, R.S. and Medeiros, E.A.A., Food Bioprocess. Technol., 5, 1447 (2012).

Franklin, N.M., Rogers, N.J., Apte, S.C., Batley, G.E., Gadd, G.E. and Casey, P.S., Comparative toxicity of nanoparticulate $\mathrm{ZnO}$, Bulk $\mathrm{ZnO}$, and $\mathrm{ZnCl}_{2}$ to a freshwater microalga (Pseudokirchneriella subcapitata): the importance of particle solubility, Environ. Sci. Technol., 41, 8484 (2007).

Gilani, S., Ghorbanpour, M., Jadid, A.P., Antibacterial activity of $\mathrm{ZnO}$ films prepared by anodizing, J. Nanostructure Chem., 6, 183 (2016).

Ghorbanpour, M. and Falamaki, C., A novel method for the production of highly adherent $\mathrm{Au}$ layers on glass substrates used in surface plasmon resonance analysis: substitution of $\mathrm{Cr}$ or $\mathrm{Ti}$ intermediate layers with $\mathrm{Ag}$ layer followed by an optimal annealing treatment, Journal of Nanostructure in Chemistry, 3, 1 (2013).

Ghorbanpour, M. and Falamaki, C., Micro energy dispersive x-ray fluorescence as a powerful complementary technique for the analysis of bimetallic $\mathrm{Au} / \mathrm{Ag} / \mathrm{glass}$ nanolayer composites used in surface plasmon resonance sensors, Applied optics, 51, 7733 (2012).

Ghorbanpour, M. and Lotfiman, S., Solid-state immobilisation of titanium dioxide nanoparticles onto nanoclay, Micro \& Nano Letters, DOI: 10.1049/mnl.2016.0259.

Gordon, T., Perlstein, B., Houbara, O., Felner, I., Banin, E. and Margel, S., Synthesis and characterization of zinc/iron oxide composite nanoparticles and their antibacterial properties, Colloids Surf. A, 374, 1 (2011).

Khaorapapong, N., Khumchoo, N. and Ogawa, M., Preparation of zinc oxide-montmorillonite hybrids, Mat. Let., 65, 657 (2011).

Kołodziejczak-Radzimska, A. and Jesionowski, T., Zinc OxideFrom Synthesis to Application: A Review. Materials, 7, 2833 (2014).

Németh, T., Mohai, I. and Tóth, M., Adsorption of copper and zinc ions on various montmorillonites: an XRD study, Acta Miner. Petrogr. Szeged, 46, 29 (2005). 
Newby, P.J., El-Gendy, R., Kirkham, J., Yang, X.B., Thompson, I.D. and Boccaccini, A.R., Ag-doped 45S5 Bioglass based bone scaffolds by molten salt ion exchange: processing and characterization, J. Mater. Sci. Mater. Med., 22, 557 (2011).

Sawai, J., Shoji, S., Igarashi, H., Hashimoto, A., Kokugan, T., Shimizu, M. and Kojima, H., Hydrogen peroxide as an antibacterial factor in zinc oxide powder slurry. J. Ferment. Bioeng., 86, 521 (1998).

Oven, R., Yin, M. and Davies, P.A., Characterisation of planar optical waveguides formed by copper-sodium, electric field assisted, ion exchange in glass, J. Phys. D Appl. Phys. 37, 2207 (2004).

Payami, R., Ghorbanpour, M., Jadid, A.P., Antibacterial silverdoped bioactive silica gel production using molten salt method, J. Nanostructure Chem., 6, 215 (2016).

Pouraboulghasem, H., Ghorbanpour, M., Shayegh, R., Antibacterial Activity of Copper-doped Montmorillonite Nanocomposites Prepared by Alkaline Ion Exchange Method, Journal of Physical Science, 27,1 (2016a).

Pouraboulghasem, H., Ghorbanpour, M., Shayegh, R., Lotfiman,, Synthesis, characterization and antimicrobial activity of alkaline ion-exchanged $\mathrm{ZnO} /$ bentonite nanocomposites. J. Cent. South Univ., 23, 787 (2016b).

Rhim, J.W. and Wang, L.F., Preparation and characterization of carrageenan-based nanocomposite films reinforced with clay mineral and silver nanoparticles, App. Clay Sci., 97-98, 174 (2014).

Srivastava, V., Gusain, D. and Sharma Y.C, Synthesis, characterization and application of zinc oxide nanoparticles (n-ZnO). Ceram. Int., 39, 9803 (2013).

Tagantsev, D.K., Lipovskii, A.A., Schultz, P.C. and Tatarintsev, B.V., Phosphate glasses for GRIN structures by ion exchange, J. Non-Cryst. Solids, 354, 1142 (2008).

Xu, C.Y., Zhen, L., Yang, R. and Wang, Z.L., Synthesis of SingleCrystalline Niobate Nanorods via Ion-Exchange Based on Molten-Salt Reaction, J. Am. Chem. Soc., 129, 15444 (2007).

Yamamoto, O., Influence of particle size on the antibacterial activity of zinc oxide, Int. J. Inorg. Mater, 3, 643 (2001).

Zhu, Y. and Zhou Y., Preparation of pure ZnO nanoparticles by a simple solid-state reaction method, Appl. Phys. A, 92, 275 (2008). 
